\title{
Sexual Harassment Against Women on German Online Media: Ideology and Cultural Study
}

\author{
Shany Pebrianti ${ }^{1}$, Aceng Ruhendi Syaifullah ${ }^{2}$, Dadang Sudana ${ }^{3}$ \\ \{Shanypebrianti@gmail.com ${ }^{1}$, Acengruhendisyaifullah@upi.edu ${ }^{2}$ \} \\ Universitas Pendidikan Indonesia ${ }^{1,2,3}$
}

\begin{abstract}
The purpose of this study is to reveal how women are represented based on German online news. The source of this research is about sexual harassment against women on German online media Tagesspiegel. This research uses the CMDA Herring method to express the context of communication in online media, as well as using the transitivity analysis of Systemic Functional Linguistics. The results showed that German online media tends to be unfavorable toward women. It was proven based on the research findings. Women victims of sexual harassment are represented as passive recipients of men's actions. The condition of women illustrating helplessness and weakness. Based on these findings, it can be concluded that German online news texts published in Tagesspiegel are gender bias.
\end{abstract}

Keywords: Representation, Sexual Harassment, German Online Media, Transitivity, $C M D A$

\section{INTRODUCTION}

Almost every day, people see or hear the news through print or electronic media. One of them is news that is discriminatory towards women. According to Mahfiana, various discrimination, indecent, and even multiple forms of crime against women, are social phenomena that occur and are experienced by women in their daily lives [1]. For example, the problem of crime against women with a violent mode, the challenge of sexual violence, is not a "something" new in people's lives. Sexual harassment against women is a global issue. In various countries, sexual violence against women has always been a very frightening specter for women. In Germany, for example, quoted from the media survey wonderlist.com Germany ranks fourth in the country for the level of sexual harassment on women in the world. In addition, the top-ranking from Germany is India, with the highest level of rape.

Meanwhile, based on data published in bka.de regarding reports on the assessment of criminal statistics against women, it is estimated that sexual harassment against women report in Germany continues to increase. Harassment against women is divided into several categories, said BKA President Holger Münch, "in the evaluation reported in the police, we found resistance to women who have various kinds such as humiliation, psychological, verbal and physical intimidation for rape and murder" . These data reveal the facts of violence against women in Germany. It often appears every year. Information about other cases of violence against women can be obtained by comparing news related to news both in conventional media such as newspapers and online media such as online newspapers.

The Germans have relatively high trust in the news, which is as much (50\%) [2]. Based on statista.com media survey, the number of visits (online and mobile) news portals in Germany in 
November 2018 had more than 546 million visits. Whereas, based on research conducted by the Order and Durner (2018) on the use of the media against young people in Germany, it is shown that the daily newspapers are the most widely chosen by young men and women are the Spiegel daily and the most daily newspapers. A bit of interest among young people is Bild [3].

Some research in the field of linguistics, such as that conducted out by [4] Leifermann (2018), found that the mass media in the European region of specifically Germany has unfavorable findings on women. Based on his research, in conservative German newspapers and most of the public, harassment is individual responsibility or systemic problems in certain industries and not gender inequality issues. Especially compilation of sexual harassment issues in their countries also see the tardiness of legislation on section harassment which is applied in Germany, this is intended as a section of harassment that is not considered to have high relevance in German society and culture.

Previous studies on the issue of harassment against women have done a lot but just watched aspects of form and violence against women [5] [6] [7] [8] [9] [10] [11]. Considering the previous research above, it can be seen in research on violence against women that has been done. However, the study of women's representation from ideological and cultural studies is rarely discussed in linguistics, especially in the context of online media in Germany.

So, its becomes an opportunity for me to see and describe the representation of women in a study of ideology and culture. How are women represented in German online news texts? (a) how does the online media of the Tagesspiegel report harassment towards women by Germans against Germans? (b) how does the online media of the Tagesspiegel report harassment towards women by non-Germans against Germans?

\section{METHOD}

This study uses a qualitative approach to obtain in-depth and comprehensive information related to research problems[12]. Qualitative research is a form of how the researcher makes interpretations based on what they see, hear, and understand. Moreover, the overall purposes of qualitative research are to achieve an understanding of how people make sense out of their lives, to delineate the process (rather than the outcome or product) of meaning-making, and to describe how people interpret what they experience [13]. In this research, I analyzed and described the data obtained by using the CMDA Herring approach, which is concentrated on the transitivity analysis developed by Halliday. I use transitivity analysis, which includes three things, such as process, participant, and circumstance, to analyze the discourse of cases of sexual harassment against women in German online media. Through this analysis, I can conclude how women are represented in the German online news text Tagesspiegel.

The data collection steps were (1) searching and reading news on several German online media related to cases of sexual harassment against women in Germany, (2) choosing Tagesspiegel online media as a source of data in this research, (3) choosing news texts to be used as research samples, (4) conducting a mapping by divided news texts into two categories based on who is the perpetrator and the victim, (5) making a general description of texts, (6) conducting an analysis using transitivity by looking at the process, participants and circumstances related to cases of sexual harassment against women in Germany. Then a discussion on the findings of the research is carried out in each section, conducted an analysis, and described the results of the transitivity analysis to find out how women are represented in the German online news text. 


\section{RESULT AND DISCUSSION}

Based on research questions: How are women represented in German online news texts? (a) how does the online media of the Tagesspiegel report harassment towards women by Germans against Germans? (b) how does the online media of the Tagesspiegel report harassment towards women by non-Germans against Germans?

\subsection{Findings}

It was found that the transitivity analysis of the Tagesspiegel text with the category of German perpetrators - German victims gave rise to 30 material processes, 8 mental, 22 verbal, 1 relational, 2 behavioral and 1 existential. Furthermore in the category of non-German perpetrators - German victims found 35 material processes, 11 mental, 26 verbal, 4 relational, 4 behavioral and 2 existential.

Table 1. Types of processes and their appearance in the Tagesspiegel Online news text

\begin{tabular}{cccccc}
\hline No. & Process Type & $\begin{array}{c}\text { Category: German } \\
\text { perpetrators - } \\
\text { German victims }\end{array}$ & $\mathbf{\%}$ & $\begin{array}{c}\text { Category: Non- } \\
\text { German perpetrators } \\
\text { - German victims }\end{array}$ & \% \\
\hline 1 & Material & 30 & 46,9 & 35 & 42,7 \\
\hline 2 & Mental & 8 & 12,5 & 11 & 13,4 \\
\hline 3 & Verbal & 22 & 34,3 & 26 & 31,7 \\
\hline 4 & Relational & 1 & 1,6 & 4 & 4,9 \\
\hline 5 & Existential & 1 & 1,6 & 2 & 2,4 \\
\hline 6 & Behavioural & 2 & 3,1 & 4 & 4,9 \\
\hline & Total & $\mathbf{6 4}$ & $\mathbf{1 0 0 \%}$ & $\mathbf{8 2}$ & $\mathbf{1 0 0 \%}$ \\
\hline
\end{tabular}

Table 1 above showed that the process type in the Tagesspiegel online news texts was dominated by material process and verbal process. According to Gerot and Wignell [14] (material) as a conversation from storytelling and (verbal) is a retelling. In this case, the news writer used storytelling and retelling as a form of realization of the discourse [15].

Table 2. The example of a material process analysis found in the text

\begin{tabular}{cccc}
$\begin{array}{l}\text { Berliner Polizist } \\
\text { Berlin Police }\end{array}$ & $\begin{array}{l}\text { wegen möglicher } \\
\text { possibility }\end{array}$ & $\begin{array}{l}\text { Vergewaltigung } \\
\text { rape }\end{array}$ & $\begin{array}{l}\text { in Untersuchungshaft } \\
\text { in prison }\end{array}$ \\
\hline Actor & Conj. & Pr. Material & Cir. Location; Place \\
\hline
\end{tabular}

The material process is most used by Male Actors. Rapists showed their power and domination over women (victims) as well as women most often used to be targeted men's actions in the text. The choice of words used in the assessment of women is to have weaknesses. The author of the text also points out that women are portrayed as passive, negative, and submissive to men. According to Khoirunnisa, women who are described as weak means that the text is biased in representing a woman in the news text [15]. The marginalization of a woman is manifested in the form of weakening the woman's position by using a choice of words that indicate the woman's own mistakes. 
Table 3. Types of Participants and Their Appearance in the Tagesspiegel Online News Text

\begin{tabular}{cccccc}
\hline No. & Participants & $\begin{array}{c}\text { Category: German } \\
\text { perpetrators - } \\
\text { German victims }\end{array}$ & $\%$ & $\begin{array}{c}\text { Category: Non- } \\
\text { German perpetrators - } \\
\text { German victims }\end{array}$ & $\%$ \\
\hline 1 & Actor & 24 & 43,6 & 20 & 35,7 \\
\hline 2 & Senser & 7 & 12,7 & 5 & 9 \\
\hline 3 & Sayer & 20 & 36,4 & 22 & 39,3 \\
\hline 4 & Carrier & 1 & 1,8 & 4 & 7,1 \\
\cline { 2 - 6 } & Token & 0 & 0 & 0 & 0 \\
\hline 5 & Behaver & 2 & 3,7 & 3 & 3,3 \\
\hline 6 & Existent & 1 & 1,8 & 2 & $\mathbf{1 0 0 \%}$ \\
\hline & Total & $\mathbf{5 5}$ & $\mathbf{1 0 0} \%$ & $\mathbf{5 6}$ &
\end{tabular}

In table 2 above, it can be seen that participants in the Tagesspiegel text are dominated by the Actor and Sayer as the main participants in the material and verbal process. This further reinforces Gerot da Wignell's statement that the news text is a dominant realization of material (material) and retelling (verbal) events, while the existence of other processes is used to support storytelling according to news writers' perceptions. Prasetyo, in his research on women who were raped collectively in online news texts, found the presence of victims (Objects) in the text displayed from the narrator's side (subject), and his presence was not displayed in full. Still, through the testimony of others, it meant that the news gender bias [16].

Susilo found that the information presented through text was mostly sourced from law enforcement officials and perpetrators of violence itself. This is due to the lack of empathy of journalists towards women [17]. The lack of journalist empathy can be caused by a number of factors, one of which is the influence of cultural values adhered to by journalists. Cultural values in the personal journalist is growing due to the influence of cultural values that are around him. In the end, this was manifested in the content they made in the news.

Table 4. Actor's Name and Appearance in Tagesspiegel's Online News Text

\begin{tabular}{|c|c|c|c|}
\hline No. & Actor's Name & $\begin{array}{c}\text { Category: German } \\
\text { perpetrators - German } \\
\text { victims } \\
\end{array}$ & $\%$ \\
\hline \multirow[t]{7}{*}{1} & Ein älterer Mann & 1 & 4,3 \\
\hline & der Mann & 1 & 4,3 \\
\hline & Der 58-Jährige & 1 & 4,3 \\
\hline & $\operatorname{Er}$ & 2 & 8,7 \\
\hline & Die Männer & 1 & 4,3 \\
\hline & zweien der Männer im Beisein der zwei anderen & 1 & 4,3 \\
\hline & Sub Total & 7 & 30,4 \\
\hline \multirow[t]{8}{*}{2} & die Berliner Polizei & 1 & 4,3 \\
\hline & Berliner Polizist & 1 & 4,3 \\
\hline & Ein Berliner Polizist & 1 & 4,3 \\
\hline & die spanische Polizei & 1 & 4,3 \\
\hline & Polizeisprecher & 1 & 4,3 \\
\hline & Der 45-jährige Beamte & 1 & 4,3 \\
\hline & Die Experten & 1 & 4,3 \\
\hline & Sub Total & 7 & 30,4 \\
\hline
\end{tabular}




\begin{tabular}{clcc}
\hline $\mathbf{3}$ & Prostituierte & 1 & 4,3 \\
\hline & der Frau & 3 & 13,0 \\
\hline die 27-Jährige & 1 & 4,3 \\
\hline Die Deutsche & 1 & 4,3 \\
\hline die junge Frau & Sub Total & 1 & 4,3 \\
\hline & & 7 & $\mathbf{3 0 , 4}$ \\
\hline $\mathbf{4}$ & sie & 2 & 8,7 \\
\hline & Sub Total & $\mathbf{2}$ & $\mathbf{8 , 7}$ \\
\hline & Total & $\mathbf{2 3}$ & $\mathbf{1 0 0 \%}$ \\
\hline
\end{tabular}

Table 5. Actor's Name and Appearance in Tagesspiegel's Online News Text

\begin{tabular}{|c|c|c|c|}
\hline No. & Actor's Name & $\begin{array}{c}\text { Category: Non-German } \\
\text { perpetrators - German victims }\end{array}$ & $\%$ \\
\hline \multirow[t]{7}{*}{1.} & Acht Männer & 1 & 5 \\
\hline & die Männer & 1 & 5 \\
\hline & zwei Männern & 1 & 5 \\
\hline & zehn Männer & 1 & 5 \\
\hline & Der Mann & 1 & 5 \\
\hline & Er & 1 & 5 \\
\hline & Sub Total & 6 & 30 \\
\hline \multirow[t]{3}{*}{2.} & sie & 1 & 5 \\
\hline & Die meisten von ihnen & 1 & 5 \\
\hline & Sub Total & 2 & 10 \\
\hline \multirow[t]{5}{*}{3.} & Die Polizei & 3 & 15 \\
\hline & ein Richter & 1 & 5 \\
\hline & Ermittler & 1 & 5 \\
\hline & eine 13 Beamten zählende Ermittlergruppe & 1 & 5 \\
\hline & $\begin{array}{ll}\text { Sub Total } \\
\end{array}$ & 6 & 30 \\
\hline \multirow[t]{3}{*}{4.} & einen der mutmaßlichen Täter & 1 & 5 \\
\hline & einem Unbekannten & 1 & 5 \\
\hline & Sub Total & 2 & 10 \\
\hline \multirow[t]{2}{*}{5.} & dem Mittäter & 1 & 5 \\
\hline & Sub Total & 1 & 5 \\
\hline \multirow[t]{5}{*}{6.} & der Afghane Hussein K. & 1 & 5 \\
\hline & $\begin{array}{l}\text { einem } 21 \text { Jahre alten Flüchtling aus } \\
\text { Afghanistan }\end{array}$ & 1 & 5 \\
\hline & Ein Afghane & 1 & 5 \\
\hline & Sub Total & 3 & 15 \\
\hline & Total & 20 & $100 \%$ \\
\hline
\end{tabular}

From tables 4 and 5 above, it can be seen that men are placed as actors. While women are only shown a few as actors. The perpetrators (men) are placed as Actors, while victims (women) are placed as Goals.

But the difference in the category of non-German perpetrators - German victims shows that the perpetrators are the most placed as actors, and women are not placed at all as actors. Owens and Hawes (2015) men act more as actors, and women are more often targeted (Goal) [18]. This may be a strategy to maintain male sexual dominance. This is supported by the findings of Sriwimon and Zilli, that various roles as seen, the reader will recognize him mainly through the role of Actor (the person acting) [19]. Then Hidayat states that if the position of women (victims) 
as the dominant object in the news is accompanied by sexist words and the identity of the victim that has not been completely disguised, it means that the news also does not yet have gender sensitivity [20].

Circumstance analysis of the text Tagesspiegel with the categories of German perpetrators towards German victims found there were 48 circumstances, then the category of non-German perpetrators towards German victims contained 62 circumstances. The following details the circumstantial findings in the two categories are described in the table below.

Table 6. Circumstances Types and Their Appearance in the Tagesspiegel Online Text Text

\begin{tabular}{|c|c|c|c|c|}
\hline \multirow[b]{2}{*}{ No } & \multirow{2}{*}{\multicolumn{2}{|c|}{ Circumstances Types }} & \multicolumn{2}{|c|}{$\begin{array}{r}\text { Categories } \\
\end{array}$} \\
\hline & & & $\begin{array}{l}\text { German perpetrators - } \\
\text { German victims }\end{array}$ & $\begin{array}{c}\text { Non German } \\
\text { perpetrators - } \\
\text { German victims }\end{array}$ \\
\hline \multirow[b]{2}{*}{1} & \multirow[b]{2}{*}{ Extent } & Duration & 2 & 2 \\
\hline & & Distance & - & - \\
\hline \multirow[b]{2}{*}{2} & \multirow[b]{2}{*}{ Location } & Time & 12 & 20 \\
\hline & & Place & 20 & 27 \\
\hline \multirow[b]{2}{*}{3} & \multirow[b]{2}{*}{ Cause } & Reason & 2 & 1 \\
\hline & & Purpose & 2 & 1 \\
\hline \multirow{3}{*}{4} & \multirow{3}{*}{ Manner } & Comparison & - & 2 \\
\hline & & Quality & 3 & 2 \\
\hline & & Degree & - & 1 \\
\hline 5 & Contingency & & 1 & 1 \\
\hline 6 & Accompaniment & & 2 & 2 \\
\hline 7 & Role & & - & 1 \\
\hline 8 & Angle & & 4 & 2 \\
\hline & Total & & 48 & 62 \\
\hline
\end{tabular}

In the analysis of circumstances, the news appears to place the location of circumstances more than any other circumstance. The findings of the location circumstantial analysis showed that Tagesspiegel described victims in each of the detailed incidents.

In addition to Halliday's transitivity analysis theory, I conducted an analysis using the Herring Computer-Mediated Discourse Analysis (CMDA) approach to uncover media factors and communication situations in German online media. It is because the news text used as data is online news text so that it distinguishes the news text online with conventional news. In this section, I found that in the context of media factors, there are ten categories, they are, the first type of communication is the textual message, and news texts can be accessed or read by anyone. The capacity of the text is unlimited. But there is no video and sound, only images as news cover images. German citizens dominate the identity of the news text writer. But, some words are gender-biased. Objective opinions are directed at the topic of discussion in the media. There is also a comment column and then title, author's name, date of the news release. Further, findings on the context situation of the communication are German-language news and writers have their respective ideologies. The theme of the news in the German online news text published in the daily Tagesspiegel is related to discrimination against women in Germany. Respondents 
regarding reporting discrimination against women, the situation tends to be confrontational and tends to use informal language.

Ideology and Culture: Patriarchy culture still attached to the way of treating women in Germany. News writers have placed male subjects as strong individuals while women are weak.

\subsection{Discussion}

This research has similarities with Leifermann's in 2018 studies with the title The Framing of Sexual Harassment in German Online Newspapers: A Critical Discourse Analysis of the Online News Coverage of the Two Biggest German Newspapers on Sexual Harassment in the Light of \#MeToo in Late 2017 [4]. But the difference sits in the data and the method used. He used Critical discourse analysis, and I used transitivity analysis. The results of his research showed that the journalist's authors of the article about the offer of a stronger subject position for men who are involved than women. While at the level of social practices, awareness of sexual harassment as a serious and systemic problem of gender inequality and conversation in Germany is relatively hampered. Furthermore, research conducted by Mannila in 2017 [21], the similarity with my research sits in the research question. Research conducted by Eilermann in 2018 also about critical discourse analysis about the discursive construction of the German news media from the hashtag \#MeToo [22]. In his conclusion, he argues that Germany upholds patriarchal values.

Hellmann et al., in 2018, his research aims to obtain current estimates of the prevalence of sexual violence against women in Germany. In their research, Helmann et al. analyzed data from the $\mathrm{N}=4450$ survey of women representing the German population, conducted by the Criminological Research Institute of Lower Saxony in 2011 [23]. The results of his research found that women experienced sexual violence of 5.4\% for women aged 21-40 years (prevalence of five years): $2.5 \%$ ). Furthermore, research that is in line with this research is a research conducted by List in 2013 entitled Sexual violence and harassment against female students in Germany discussing sexual violence and harassment of female students in Germany [24]. Then research by Steffens et al. on fact sheets of domestic violence (violence in partner relationships) and sexual violence against women revealed incidents of violence higher than the average experienced by women in Germany compared to other EU countries. Research conducted by Varghese and Sarkute (2017), has in common with this research, which is trying to find out the role of the media in describing reports of violence against women in Germany conducted by men with immigrant backgrounds [25]. The research method used in his research includes analysis of documents from various aspects of violent incidents. It is done by observing news reported from July 2016 to February 2017 by two English language news portals available online, one from Germany www.thelocal.de and the other is e-portal new international www.express.co.uk. Also, secondary data analysis from various statistics such as crime statistics from Germany, reports of migration from Eurostat, reports of violence by the European Union Agency for Fundamental Rights (FRA), etc. used in his research. Regarding the analysis in his research, it can be seen that the local German news media hid most of the incidents in fear that there would be a clash between local residents and immigrants.

\section{CONCLUSION}

Based on the findings and analysis of transitivity, it appears that news about sexual harassment against women in Tagesspiegel tends to represent victims of sexual harassment 
negatively. Women are described as passive recipients of male actions, and women are described as weak people. This online news text has an indication of gender bias. Patriarchy culture still attached to the way of treating women in Germany. News writers have placed male subjects as strong individuals while women are weak both in the category of German perpetrators - German victims and non-German perpetrators - German victims.

Acknowledgments. I would like to express my deepest appreciation to all those who provided me the possibility to complete this report. A special gratitude I give to my supervisor, Mr. Aceng Ruhendi Syaifullah Dr., M. Hum. and Mr. Dadang Sudana, M.A, Ph.D., whose contribution in stimulating suggestions and encouragement, helped me to coordinate my project, especially in writing this report.

\section{REFERENCES}

[1] L. Mahfiana, "Perempuan dan Diskriminasi (Studi Kebijakan Pemerintah Daerah dalam Penghapusan Diskriminasi terhadap Perempuan)," J. Al-'Adl, vol. 8, no. 2, pp. 110-122, 2015.

[2] N. Nic, D. A. L. Levy, and R. K. Nielsen, "Reuters Institute Digital News Report 2018," Univ. Oxford, vol. 1, pp. 1-139, 2018, doi: 10.1017/CBO9781107415324.004.

[3] H. vom Orde and D. Alexander, Grunddaten Jugend und Medien 2018 Aktuelle Ergebnisse zur Mediennutzung von Jugendlichen in Deutschland. Internationales Zentralinstitut für das Jugend und Bildungsfernsehen (IZI). München: Rundfunkplatz, 2018.

[4] R. Leifermann, "The Framing of Sexual Harassment in German Online Newspapers: A Critical Discourse Analysis of the Online News Coverage of the Two Biggest German Newspapers on Sexual Harassment in the Light of \#MeToo in Late 2017," Malmö University, 2018.

[5] K. Fairchild and L. A. Rudman, "Everyday stranger harassment and women's objectification,” Soc. Justice Res., vol. 21, no. 3, pp. 338-357, 2008, doi: 10.1007/s11211-008-0073-0.

[6] K. Fairchild, "Context effects on women's perceptions of stranger harassment," Sex. Cult., vol. 14, no. 3, pp. 191-216, 2010, doi: 10.1007/s12119-010-9070-1.

[7] L. K. Prakash, "Catcalling, Sexual Harassment and Sexual Discrimination: Unpacking a Deep-rooted Anti-social Pattern through CDA, MCDA and Corpus Analysis," Mae Fah Luang University, Chiang Rai, Thailand, 2012.

[8] C. Brouwers, "How you doing? A linguistic analysis of the street harassment video by Bliss and Roberts (2014)," Leiden University. Netherlands, 2015.

[9] O. Farmer and S. Smock Jordan, "Experiences of Women Coping With Catcalling Experiences in New York City: A Pilot Study," J. Fem. Fam. Ther., vol. 29, no. 4, pp. 205-225, Oct. 2017, doi: 10.1080/08952833.2017.1373577.

[10] M. T. C. Payares and V. P. Naranjo, "CATCALLING AS A FORM OF VIOLENCE AGAINST WOMEN IN THE CITY OF CARTAGENA. Maria," Fundacion Universitaria Colombo Internacional UNICOLOMBO, 2017. 
[11] H. Mac Arthur, A Sociolinguistic Analysis of the Catcall as a Speech Act. Florida International University, 2018.

[12] J. W. Creswell, Educational Research Planning, Conducting and Evaluating Quantitative and Qualitative Reserach, 4th editio. Boston: Pearson Education, 2012.

[13] S. B. Merriam and E. J. Tisdell, Qualitative Research: A Guide to Design and Implementation, 4th editio. United States of America: Jossey-Bass, 2015.

[14] L. Gerot and P. Wignell, Making Sense of Functional Grammar. Sidney: Gerd Stabler, 1994.

[15] A. Khoirunisa, "Peran Perempuan dalam Berita Pelecehan Seksual pada Jakarta detik.com (Pendekatan Analisis Wacana Model Sara Mills)," Deskripsi Bhs., vol. 01, no. 01, pp. 26-30, 2018.

[16] D. E. Prasetyo, "Analisis Berita Yuyun dan Para Korban Kejahatan Akibat Minuman Keras di Republika Online edisi 7 Mei 2016," Dunia Komun., vol. 4, no. 3, 20016.

[17] D. Susilo and E. Haezer, "Konstruksi Seksualitas Perempuan Dalam Berita Pemerkosaan Di Teks Media Daring," J. Kawistara, vol. 7, no. 1, p. 41, 2017, doi: 10.22146/kawistara.15636.

[18] J. E. Owens and T. P. Hawes, "Language choice and the representation of women and men in two British newspapers," Journal. Discourse Stud., vol. 1, no. 1, pp. 1-22, 1995.

[19] L. Sriwimon and P. J. Zilli, "Applying Critical Discourse Analysis as a conceptual framework for investigating gender stereotypes in political media discourse,"

Kasetsart J. Soc. Sci., vol. 38, no. 2, pp. 136-142, 2017, doi: 10.1016/j.kjss.2016.04.004.

[20] M. T. Hidayat, R. Iswari, and N. S. Akhiroh, "Citra Perempuan Dalam Berita Kekerasan Seksual,” Solidar. J. Educ. Soc. Cult., vol. 6, no. 2, pp. 148-155, 2017.

[21] S. Mannila, WOMEN AND MEN IN THE NEWS: REPORT ON GENDER REPRESENTATION IN NORDIC NEWS CONTENT AND THE NORDIC MEDIA INDUSTRY. Rosendahls Denmark: Nordic Council of Ministers, 2017.

[22] W. Eilermann, "Constructing \#MeToo A Critical Discourse Analysis of the German News Media's Discursive Construction of the \#MeToo Movement," School of Arts and Communications, 2018.

[23] D. F. Hellmann, M. W. Kinninger, and S. Kliem, "Sexual violence against women in germany: Prevalence and risk markers," Int. J. Environ. Res. Public Health, vol. 15, no. 8, 2018, doi: 10.3390/ijerph15081613.

[24] K. Lista, "Sexual violence and harassment against female students in Germany," Riv. di Criminol. Vittimologia e Sicur., vol. VII, no. 2, 2013.

[25] T. Varghese and L. Sarkute, "Violence Against Women in Germany and Immigrants: a Mediatized Political Communication?," Eur. Integr. Stud., vol. 0, no. 11, pp. 31-43, 2017, doi: 10.5755/j01.eis.0.11.18957. 
